\title{
重複癌 統計的観察
}

\section{当科における最近 2 年間の重複癌}

寺内 雅美*

\section{Summary}

While the survival rate of malignant tumor patients is recently improving along with progress in the medical care technology, the incidence of secondary cancer after the cure of the first cancer is also increasing because of the aging of patients. An increase in the incidence of malignant tumor of other organs in addition to primary malignant skin cancer has also been noted in my department. I report on the polyoncosis cases I experienced during the 2 years from January 1995 to December 1996.

Of the malignant skin tumor patients treated during the 2 years, polyoncosis was observed in 2 of the 3 patients with Paget disease and 5 of the 30 patients with squamous cell carcinoma. The types of duplicate cancers included lung cancer(3), gastric cancer(2), laryngeal cancer(2), hepatocelular carcionoma(1), prostate carcinoma(1) and multiple myeloma(1). One patient had 3 cancers and another had 4 cancers. The age of patients ranged from 66 to 81 years old (mean 72.2 years old).

A high healing ratio of malignant skin tumor can be obtained in many cases by considerably less invasive methods. On the other hand, radical invasion is needed to cure the malignant tumor of other organs, and the treatment method is restricted by various considerations including the age, lesion, progress of cancer, prognosis, general condition and the will of patient. In this regard, I try to communicate with the patient and his/her family, and obtain their understanding so that he/she can receive the treatment satisfactory to him/her.

\section{はじめに}

\section{重複癌とは「独立して発生した癌が同じ患者} に2 個以上できたもので，転移・再発の場合は いれない」と理解されている1)。近年悪性腫瘍の 診断・治療成績が向上し患者の生命的予後が改

\footnotetext{
* Masami TERAUCHI：沼津市立病院形成外科
}

善したきたため重複癌の増加が懸念されてきて いる。当科において1995年 1 月より1996年12月 までの 2 年間に 7 例の重複癌を経験したので, 若干の考察を加之報告する。

\section{症例}

1995年 1 月より 12 月までに当科で手術を行っ た皮膚悪性腫瘍は63例, 1996年は76例であった。 そのうち重複癌は外院部 Paget 病と有棘細胞 
癌にみられ, Paget 病は1995年 1 例中 1 例, 1996 年が 2 例中 1 例であった。有棘細胞癌では1995 年は13例中 1 例， 1996年では 17 例中 4 例であっ た（表 1 )。

重複した癌の種類は三重複および四重複を含 んでおり, 肺癌 3 例, 胃癌 2 例, 喉頭癌 2 例, 肝癌 1 例, 前立腺癌 1 例, 多発性骨髄腫 1 例で あった（表 2 )。

症例一覧と代表例を紹介寸る。

外陰部 Paget 病と重複癌(表 3 )：81歳の四 重複癌と75歳肺癌重複のいずれも男性であっ

表 1。1995 1996年間の皮膚悪性腫瘍の症例数と重 複癌の頻度

\begin{tabular}{lcc}
\hline & 1995 & 1996 \\
Paget病 & $1 / 1$ & $1 / 2$ \\
有棘細胞癌 & $1 / 13$ & $4 / 17$ \\
皮膚悪性腫瘍 & 63 & 76 \\
\hline
\end{tabular}

表 2。重複内蔵癌の種類

（三重複および四重複を含む）

\begin{tabular}{ll}
\hline 肺癌 & 3 例 \\
胃癌 & 2 例 \\
喉頭癌 & 2 例 \\
肝癌 & 1 例 \\
前立腺癌 & 1 例 \\
骨髄腫 & 1 例 \\
\hline
\end{tabular}

表 3. 乳房外 Paget 病と重複癌

1.81歳，男性：1995年10月当科手術

$\begin{array}{ll}\text { 喉頭癌 } & \text { 1994年 } 5 \text { 月 } \\ \text { 肺癌 } & \text { 1996年 } 4 \text { 月 } \\ \text { 前立腺癌 } & \text { 1996年 } 8 \text { 月 }\end{array}$

2. 75歳，男性：1996年11月当科手術

肺癌

1996年11月
た。

症例 $1 ： 81$ 歳, 男性（表 3，1）

当科手術：1995年10月（図 1，2）

既往歴：喉頭癌 $\left(\mathrm{T}_{1 \mathrm{a}} \mathrm{N}_{0} \mathrm{M}_{\mathrm{x}}\right)$ のため1994年 5 月喉頭摘出術施行した（図 3 )。

当科術後経過：1996年 4 月肺扁平上皮癌 $\left(\mathrm{CT}_{2} \mathrm{~N}_{3} \mathrm{M}_{0}\right.$ StageIIIb)のため放射線治療を行っ

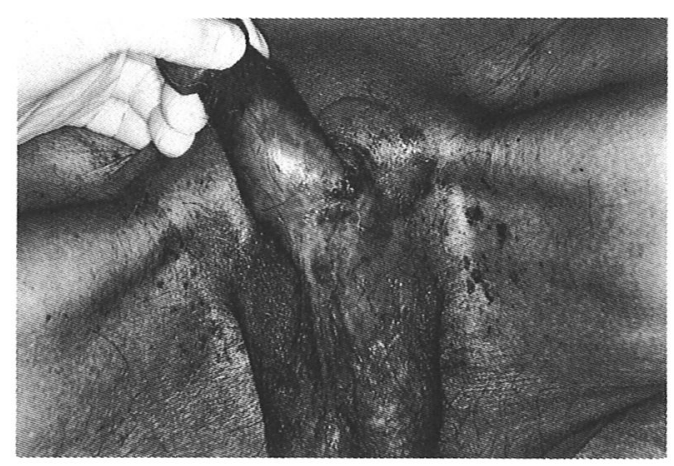

図 1. 症例 1, 外陰部 Paget 病

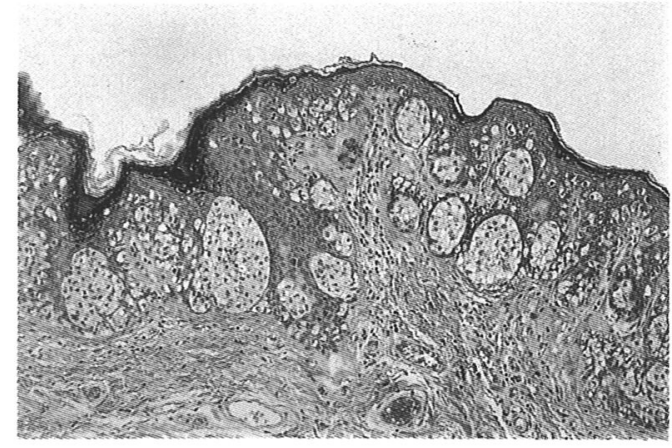

図 2. 症例 1, Paget 病 組織所見

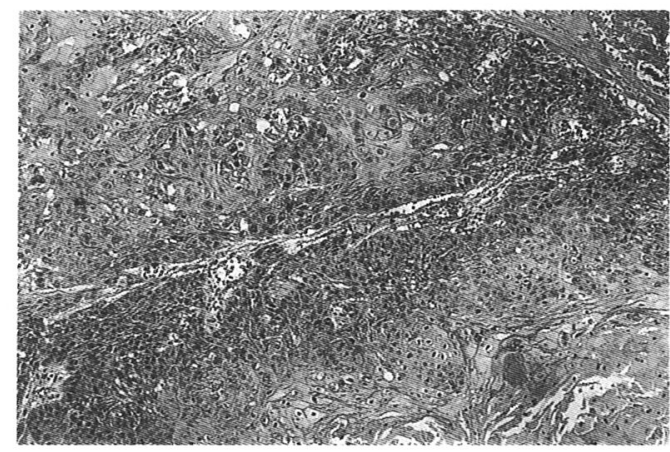

図 3。症例 1 , 喉頭癌 組織所見 
た。さらに1996年 8 月前立腺癌 $\left(\mathrm{T}_{1 \mathrm{c}} \mathrm{N}_{2} \mathrm{M}_{0}\right.$ Gleason I ）のためホルモン療法が施行された (図 4 )。

1997年 3 月呼吸困難のため内科受診，肺癌の 進展を指摘され自宅加療を希望し，以後通院中 止となった。

症例 $2 ： 75$ 歳, 男性（表 3，2）

現病歴：当院皮䖉科生検にて外陰部 Paget 病と診断されたため，根治術を目的として当科 紹介となった。当科術前検查で胸部異常陰影が みられたため内科精查依頼したところ， ${ }_{c} \mathrm{~T}_{2} \mathrm{~N}_{0}$ $\mathrm{M}_{1}$ StageIII扁平上皮癌と診断された（図 5 ）。

肺癌治療をすすめるも本人拒否し，外陰部 Paget 病治療に関しても入院期間の短縮と症痕 を最小限度にしたいと希望したため，承諾した 範囲で Paget 病の切除，皮膚移植を行った (図 6 )。退院後再来しない。

有棘細胞癌と重複癌(表 4)：66歳から76歳ま で 5 例みられ全例女性だった。

症例 3：76歳，女性（表 4, 1）

当科診断：下口唇有棘細胞癌のため 1995 年 7 月手術施行した（図 7，8，9）。

当科術前検查で $\mathrm{HCV}$ 抗体陽性のため内科精 査依頼したところ肝癌および胃癌が発見され， 1996年12月外科にて手術施行された。肝癌は $\mathrm{V}_{\mathrm{p} 0}, \mathrm{~V}_{\mathrm{v} 0}, \mathrm{IMT}, \mathrm{W}\left(\right.$ 一), 胃癌は $\mathrm{P}_{0}, \mathrm{H}_{0}, \mathrm{~N}_{1}$, $\mathrm{T}_{2}$ であった（図10，11）。

現在経過観察中で，内臟腫瘍転移のため放射 線治療後通院中である。

症例 4：73歳，女性（表 4，5）

当科診断：左下腿有棘細胞癌

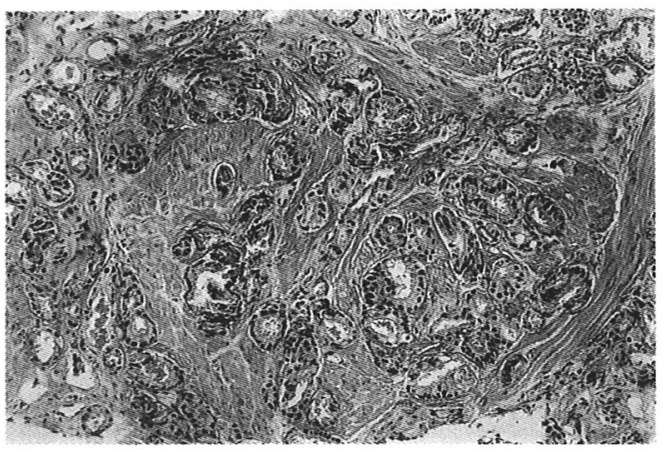

図 4 . 症例 1 , 前立腺癌 組織所見

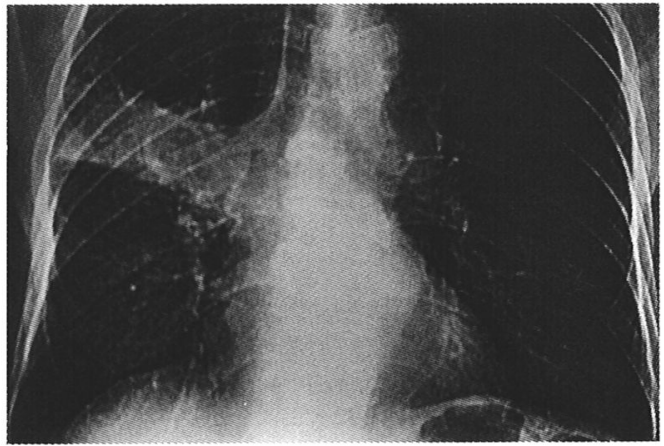

図 5.症例 2 , 胸部レントゲン所見

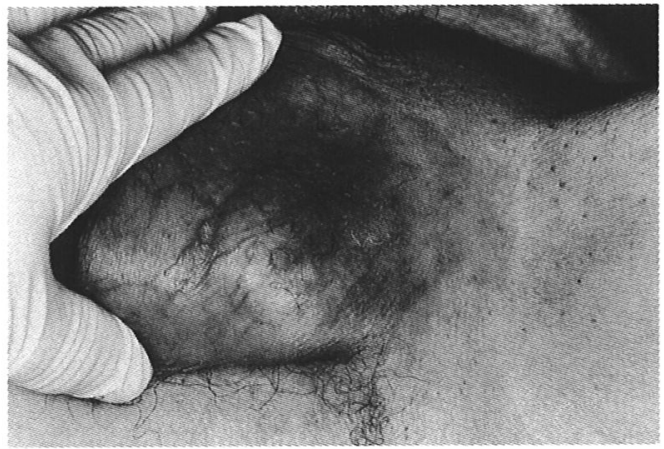

図 6. 症例 2, 外陰部 Paget 病

表 4，有輠細胞癌と重複癌

1.76歳, 女性：1995年 7 月当科手術

2. 67歳，女性：1996年 2 月当科手術

3.73歳，女性：1996年10月当科手術

4.66歳, 女性：1996年11月当科手術

5. 73歳, 女性：1996年11月当科手術 1996年11月肺癌
1996年12月胃癌・肝癌

1996年 9 月胃癌

1989年 9 月喉頭癌

1996年11月骨髄腫 


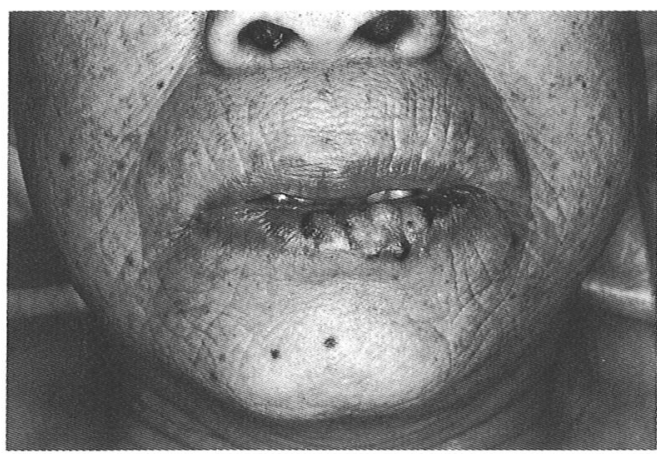

図 7. 症例 3 , 下口唇有棘細胞癌, 術前所見

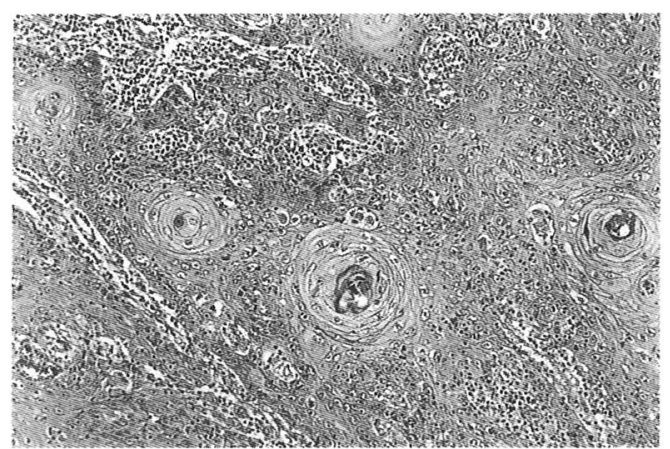

図 9. 症例 3, 下口唇 組織所見

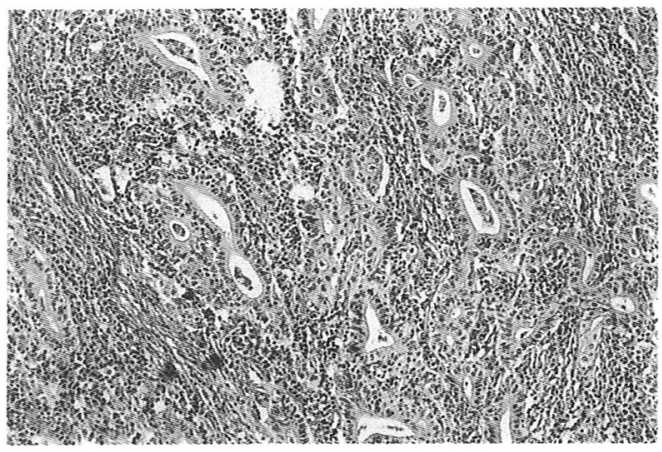

図11. 症例 3 , 胃癌 組織所見

1996年11月 $\mathrm{sT}_{4} \mathrm{~N}_{0} \mathrm{M}_{0}$ StageIIIb の扁平上皮 癌肺癌手術目的で呼吸器外科入院となった (図12)。入院時左下腿皮疹を指摘され当科紹介 され，生検の結果有棘細胞癌と診断された (図13)。

肺癌は StageIIIb で長期生存は望めないこと を考慮し，下腿腫瘍は周囲に約 $5 \mathrm{~mm}$ 離して筋

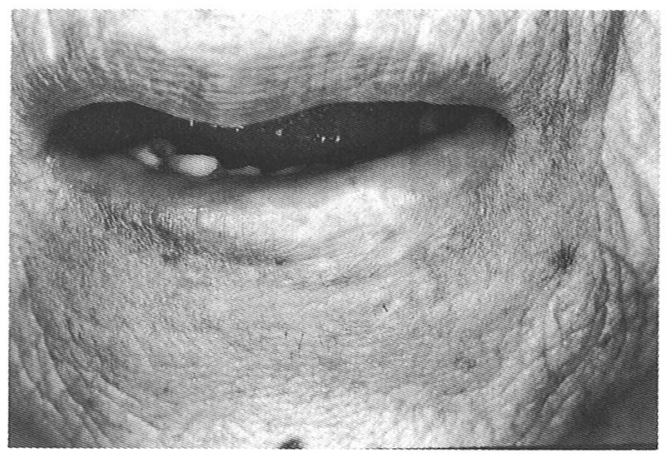

図 8. 症例 3 , 下口唇有棘細胞癌, 術後所見

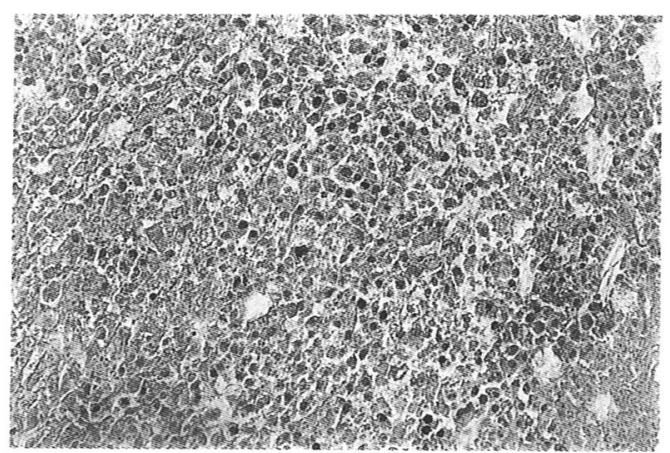

図10．症例 3，肝癌 組織所見
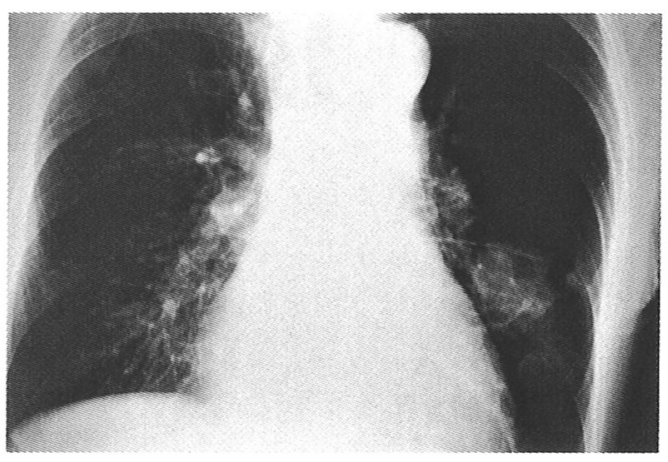

図12。症例 4 ，下腿有棘細胞癌 胸部レントゲン所見

膜上で切除，皮膚移植を行った（図14）。 術後下腿腫瘍に関しては再発・転移は認めら れず経過観察中である。

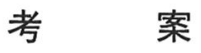

重複癌は Billrothにより初めて定義された 


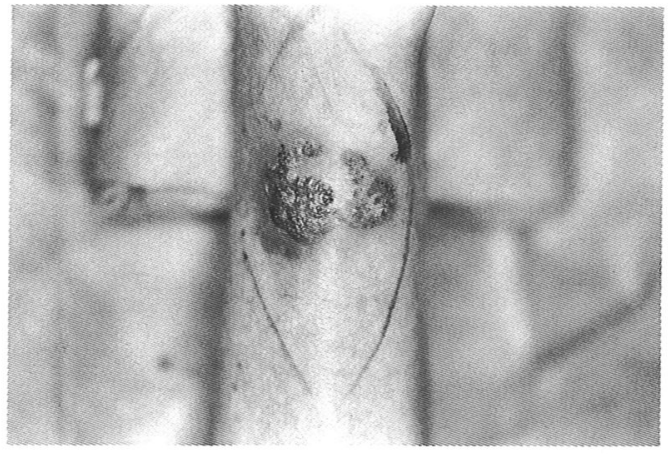

図13. 症例 4, 下腿有棘細胞癌, 術前所見と切除範囲

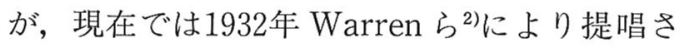
れた「1. 各腫瘍は一定の悪性像を示す 2 . 各腫瘍は別個のもの 3 . 一方の腫瘍が他の腫 瘍の転移の可能性を明らかに除外できること」 が広く用いられている。また発生間隔により同 時性と異時性, 一次癌と二次癌等の時間的関係 が問題とされる場合もある。しかし実際には発 癌の時期をとらえるのは困難であり, 最初に発 見された癌が一次癌であり, 一次癌と二次癌の 発現間隔が 1 年以内を同時性，それ以上を異時 性とされていることが多い3)。

近年医療技術の進歩に伴い悪性腫瘍の診断・ 治療成績が向上し患者の生命的予後が改善して きた。この結果, 重複癌・二次癌の発生が注目 を浴びてくるようになってきた。我国における 重複癌の好発年齢は高齢化がみられており, 1960年の北畠ら ${ }^{4)}$ の報告では50歳代に多くみら れたとしているが，1977～1979年の「日本病理 剖検輯報」によれば70歳代が最多とされてい る5)。一次癌が治癒するに従ってさらに高齢化 が進行する。一般に癌になり易さは年齢に比例 寸るといわれている6)。以前より加龄に伴って 皮膚悪性腫瘍の増加は認女られており, 高齢者 の増加による二次性皮膚癌の増加は当然と思わ れる。

重複癌の発生因子として遺伝的負荷などの宿 主因子，職業や生活習慣などの環境的因子に加

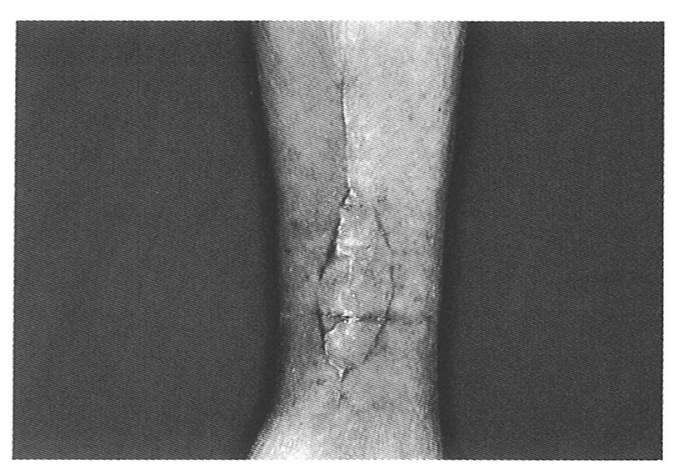

図14. 症例 4 , 下腿有棘細胞癌, 術後所見

之て化学療法や免疫療法, 放射線療法などの医 療因子による二次癌誘発も考慮すべきものと思 われる7)。

今回当施設における 2 年間の統計では重複癌 は外陰部 Paget 病と有棘細胞癌にみられた。石 原の報告8)では乳房外 Paget 病では14.3\%に重 複癌が認められ, Bowen 病に次いで多く, 有棘 細胞癌は 3 番目に多くて $6.6 \%$ にられたとし ている。特に systemic cancer proneness とい われている Bowen 病や Paget 病では内藏癌の 定期検査の重要性をあげている。当施設に於け る傾向は若干異なっており, Paget 病では 3 例 中 2 例 $(66.7 \%)$ と高頻度に，有棘細胞癌では 30 例中 5 例 $(16.7 \%$ ）であった。また石原は三 重複は有棘細胞癌に多いとしているが, 今回の 報告では外院部 Paget 病と有棘細胞癌に認め られた点が異なっている。これらの相違は症例 数の差や, 調查期間が短期間であったためと思 われる。

また過去の報告をみるまでもなく皮膚悪性腫 瘍の中で発生頻度の高い基底細胞癌では重複癌 が少ない点も興味のある点である。

重複した癌の種類は三重複および四重複を含 んでおり, 肺癌, 胃癌, 喉頭癌, 肝癌, 前立腺 癌, 多発性骨髄腫の順であった。石原の1985年 の報告では甲状腺, 胃, 乳房の順となってい る ${ }^{8)}$ 。肺癌は近年増加しており, 今後肺癌の重複 
が増加するものと思われる。

通常皮膚悪性腫瘍は早期に患者が自覚するた め, いわゆる早期発見・早期治療が可能な腫瘍 であり一般に予後は良好だが, 重複癌が発見さ れた場合は皮虐癌に対する治療法は臨機応変が 必要と思われる。すなわち二次癌・三次癌は治 療が困難なことが多く, 全身的予後不良の悪性 腫瘍と皮膚癌が重複した場合は，その根治性よ りも患者の社会的利益を優先した治療手段を執 るべきと思われる。露出部や外陰部など精神的 影響の大きい部位に瘢痕や変形を残したり，表 情を失う可能性がある場合，また入院による社 会生活の制限などを多面的に考慮し, 患者と治 療方法や予後を相談の上方針を決定すべきと思 われる。

\section{結語}

最近 2 年間に経験した 7 例の重複癌を報告し た。高齢化の進行に伴って皮膚癌を含めた重複 癌・二次癌の発生増加が懸念されており, その 治療法は症例ごとに十分検討する必要があると 思われた。
本論文の要旨は第13回日本皮䖉悪性腫瘍学会総 会·学術大会 (1997年 7 月11日～12日 於泉佐野市) において発表した。

\section{文献}

1 ）渡辺昌：日本人の癌．金原出版。東京１995、325.

2 ) Warren, S., Gates, O. : Multiple primary malignant tumors. A survey of the literature and a statiscal study. Am.J. Cancer, 16: 1359-1414, 1932.

3 ) 関根毅：重複癌とは, 臨床の立場から. 最新医学, $40: 1580-1587,1985$.

4 ）北畠隆, 金子昌生, 木戸長一郎, 他：重複悪性腫 瘍の発現頻度に関して一症例報告並じに統計的観 察一. 癌の臨床, $6: 337-345,1960$.

5 ) 日本病理学会編：日本病理剖検輯報. 第20 22輯. 日本病理剖検輯報刊行会, $1977 \sim 1979$.

6 ) Armitage, P., Doll, R., : The agedistribution of cancer and a multistage theory of carcinogenesis. Br.J. Cancer, 8: 1-12, 1954.

7 ) 小林友美子, 渡辺昌: Multiple cancer syndrome (多重癌) ; 癌の臨床, 別冊, 癌診断・治療又 ニュアル第 1 版, 篠原出版. 東京. 1989. 704-712.

8 ）石原和之：皮膚癌と重複癌. 最新医学, $40: 1675$ $-1685,1985$. 